\title{
The effect of organosolv pretreatment on optimization of hydrolysis process to produce the reducing sugar
}

\author{
Fibrillian Zata Lini, Tri Widjaja**, Nuniek Hendrianie, Ali Altway, Siti Nurkhamidah, and Yumarta Tansil \\ Chemical Engineering Department, 60111 Institut Teknologi Sepuluh Nopember, Indonesia
}

\begin{abstract}
As the fossil energy decrease such as petroleum and natural gas, that are encourages a lot of research to develop new sources of energy from renewable raw materials. One of the source is through reducing sugar (glucose and xylose) obtained from coffee pulp waste; this is due to abundant production of coffee pulp every year reaching $743 \mathrm{~kg} / \mathrm{ha}$. In addition, this waste has not been used optimally and the cellulose and hemicellulose content of the coffee is high. The purpose of this study is to get the optimal operating condition for reducing sugar production from coffee pulp waste. The method used for optimization is Response Surface Methodology with Central Composite Design. The optimum operation condition obtained was $\mathrm{pH} 4.63$ at $34^{\circ} \mathrm{C}$ for 16.29 hours of hydrolysis. As a result, the predicted yield gained was 0.147 grams of reducing sugars / gram of cellulose+hemicellulose. The result indicates the gained yield was 0.137 grams of reducing sugars / gram of cellulose+hemicellulose.
\end{abstract}

\section{Introduction}

Due to the improvements of technologies, the fossil based energy source will always decreasing, therefore the invention of renewable alternative energy sources must be developed to fulfill the energy needs (Zaldivar et al., 2001). Bioethanol is a choice of alternative energy source to replace the function of fossil based energy source. It can reduce both fossil based energy source and greenhouse effect that become main environment issue nowadays. Bioethanol itself is a renewable fuel source that will not produce extra carbon dioxide from its usage and can be categorized as clean alternative energy that can be renewed (Widjaja et al., 2014).

The most common method of bioethanol production is using sugar or starch containing materials as the raw material. Those kind of materials (sugar or starch) are commonly used either as main food source or livestock feed (Hahn-Hagerdal et al., 2006). Sugar or starch based materials for bioethanol production will make another problem, which is the food and livestock feed source will decrease. Another material can be used for bioethanol production, especially from agricultural waste that cannot be processed again such as rice straw, sorghum stem, coconut coir dust, or coffee pulp waste (Widjaja et al., 2015). By using those materials, the agricultural waste issue can be solved.

Agricultural waste consists of lignocellulosic biomass that can be converted into reducing sugar which will be fermented to produce bioethanol. The usage of lignocellulosic biomass has a very high potential to be developed due to the availability of that kind of material and lignocellulosic biomass cannot be used for either food source or main livestock feed (Geng et al., 2012). Coffee pulp waste is a lignocellulosic biomass that is very abundant in Indonesia, which can reach 743 kilograms each hectare of coffee farm. Coffee pulp waste has a high potential to be raw material to produce reducing sugar which will be fermented to produce bioethanol. Besides the biomass availability, the composition of coffee pulp consists of high cellulose and hemicellulose content which can be converted to reducing sugar. In previous study, the coffee pulp waste consist of cellulose $(58.36 \%)$; hemicellulose $(21.8 \%)$; lignin $(5.05 \%)$; protein $(0.81 \%)$; tannin (3.11\%); and pectin (2.16\% ) (Widjaja et al., 2017).

Commonly, bioethanol production process from lignocellulose biomass consists of biomass pretreatment process, hydrolysis, reducing sugar fermentation process, and then continued to separation and purification process (Cardona and Sanchez, 2007). There are commonly need three methods for pretreatment process which are organosolv, hydrothermal, and ammonium methods.

The hydrotermal pretreatment has major advantages due to no addition of chemicals and no requirement of corrosion resistant materials for hydrolysis reactors. It must be operated in high temperature and short residence time, the increasing of operating temperature causes higher saturated water vapour pressure, which results in faster hydrolysis of volatile matter contents. However, it increases the energy consumption in the pretreatment process. Furthermore, higher residence time causes pyrolysis, which results in charring of biomass along with higher energy requirement (Chandra et al., 2012).

In the previsious study (Domanski et al., 2016), the use of ammonia for pretreatment of lignocellulosic materials results in biomass swelling and increasing of biomass porosity, reduction in the degree of polymerization and the crystallinity of cellulose and an

\footnotetext{
* Corresponding author: papatri2003@yahoo.com
} 
effective delignification. Ammonia is thought to act selectively with lignin bonds, especially C-O-C bonds, as well as ester and ether bonds, which selectively reduces lignin in the lignocellulose structure. Aqueous ammonia as a chemical has several desirable traits that make it a good candidate for an industrial platform. Additionally, ammonia is relatively inexpensive, and less harmful byproducts that could inhibit enzymatic hydrolysis created from the interaction of aqueous ammonia with lignocellulosic biomass. However, most of the ammonium pretreatments require relatively high temperatures (over $100{ }^{\circ} \mathrm{C}$ ) and high pressure.

Organosolv pretreatment is a separation process of fiber using organic solvent with or without acid or base catalyst to hydrolyze lignin in biomass. This pretreatment can increase the cellulose which is effective to degrade hemicellulose or lignin and to decrease the cyrztalline. The greater the solvent concentration, the greater the reduction of lignin which results from dissolving small part of hemicellulose and increasing the cellulose. Organosolv pretreatment is carried out at $100-250^{\circ} \mathrm{C}$ with acidic catalyst. With the addition of acidic catalyst, high temperature will decompose the xylose to be furfural, hydroxylemthyl furfural and polyphenol which will inhibit the pretreatment. Another disadvantage of this method is the requirement of high amount of solvent and high energy recovery consumption. Ethanol is used as the solvent because of its cheap price. Compared to another chemical pretreatment, the advantages of Oganosolv pretreatment are a relatively pure lignin which will be produced and less energy consumption. From environmental point of view, the separation of lignin will decrease waste water treatment problem. The increasing of cellulose from the removal of lignin will increase the maximum glucose concentration (Widjaja et al., 2016).

The hydrolysis step consists of two techniques: enzymatic hydrolysis and acidic hydrolysis. Enzymatic hydrolysis process is chosen due to lower energy consumption in the process because the process is done in mild condition and its substrate specific and rarely formed byproduct from its process (Sun and Cheng, 2002). Cellulose is the main composition that will be processed to be reducing sugar and this component is very abundant in environment. Based on this reason, cellulase enzyme commonly used to hydrolyze cellulose to be glucose as reducing sugar. Beside cellulose, hemicellulose can be utilized to produce reducing sugar, especially in coffee pulp waste. Due to this reason, the combination of cellulase and xylanase enzyme in hydrolysis process must be developed to reach better reducing sugar production.

Enzymatic hydrolysis is affected by some factors which are the variety of substrate, enzyme activity and operation condition (temperature, $\mathrm{pH}$, hydrolysis time, etc.). There were many studies that focused on the optimization of production yield and rate in enzymatic hydrolysis process(Sun and Cheng, 2002). Operating condition must be optimized due to the economic terms from the intense usage of enzyme. Response surface methodology (RSM) is a statistical method that commonly used to generate optimum value from modelling and optimize variables that affect the model. This method commonly used in enzymatic hydrolysis optimization (Ferreira et al., 2009).

This study was focused on the optimization of enzymatic hydrolysis of organosolv pretreated coffee pulp using response surface methodology (RSM) with central composite design. The enzymatic hydrolysis was done using cellulase and xylanase enzyme mixture to obtain higher reducing sugar yield.

\section{Experimental}

\subsection{Coffee Pulp Pretreatment Process}

In this study, coffee pulp waste as the substrate must be pretreated before hydrolyzed in enzymatic process. The pretreatment consisted of two processes, mechanical and chemical pretreatment. In mechanical pretreatment, coffee pulp waste was dried under the sunlight for 12 hours and grinded to reach 100-120 mesh size. Grinded coffee pulp pretreated chemically using organosolv method with $50 \%$ ethanol as the solvent ${ }^{[10]}$. Coffee pulp was mixed with citric acid with 1:16 (w/w) ratio and added by $\mathrm{NaOH} 4 \mathrm{~N}$ solution until $\mathrm{pH} 3$ was reached. The coffee pulp and citric acid solution then was heated at $80^{\circ} \mathrm{C}$ for 75 minutes with stirring speed of $600 \mathrm{rpm}$. After this process, the solution was separated between solid and liquid. The solid obtained was treated by $100 \mathrm{~mL}$ of $50 \%$ ethanol solution and heated at $50^{\circ} \mathrm{C}$ in a magnetic stirrer with stirrer speed of $500 \mathrm{rpm}$ for 2 hours. The solid form after the addition of ethanol solution must be washed until the $\mathrm{pH}$ was neutral and then dried at $60^{\circ} \mathrm{C}$ until reach constant weight. The crystallinity index (CI) of celluloses and hemicellulose was measured using XRD (X'Pert PRO, PANalytical, Departement of materials and metallurgy, ITS, INDONESIA).

\subsection{Enzyme Preparation}

The enzyme used in this study was combination of pure cellulase enzyme and pure xylanase enzyme. Pure cellulase enzyme was obtained from Aspergillus niger Sigma Aldrich C1184- 25KU whereas pre-xylanase enzyme was obtained from Trichoderma longibrachiatum Sigma Aldrich X2629-100G. One gram of each enzyme was diluted with citric buffer until $100 \mathrm{~mL}$ of volume.

\subsection{Enzyme Hydrolysis}

One gram of pretreated coffee pulp was added by $18.6 \mathrm{U}$ of pure cellulase enzyme solution and $18.6 \mathrm{U}$ of pure xylanase enzyme solution. 18.6 U was obtained activity enzyme. 
Table 1. Initial Activity Enzyme Of The Cellulase And Xylanase Used In This Work.

\begin{tabular}{|c|c|c|c|}
\hline \multirow{2}{*}{$\mathrm{pH}$} & \multicolumn{2}{|c|}{ Activity Enzyme (U/mL) } & $\begin{array}{c}\text { Enzyme } \\
\text { required/ } \\
\text { one gram of } \\
\text { coffee pulp }\end{array}$ \\
\cline { 2 - 4 } & $\begin{array}{c}\text { Cellulase } \\
\text { Enzyme }\end{array}$ & $\begin{array}{c}\text { Xylanase } \\
\text { Enzyme }\end{array}$ & 20.994 \\
\hline 3 & 1.241 & 3.123 & 12.141 \\
\hline 5 & 2.523 & 3.901 & 11.262 \\
\hline 7 & 2.775 & 4.079 & \multicolumn{2}{|c}{} \\
\hline
\end{tabular}

Citric buffer was added until it reached $30 \mathrm{~mL}$ of its hydrolysis volume. The enzymatic hydrolysis was done in a shaking incubator with $125 \mathrm{rpm}$ shaking speed in various operating conditions that optimized using central composite design method.

\subsection{Optimization Technique}

Response surface methodology (RSM) is a mathematical and statistical method used for modelling purpose and problems analysis in which the variables used have direct effect on the response. This methodology was conducted to get optimum value not only for the response but also for the variables (Mesa et al., 2011).

Based on previous study, enzymatic hydrolysis was generally affected by hydrolysis temperature, $\mathrm{pH}$, and hydrolysis time (Hamada et al., 2013). In this study, these factors were used as the main factors that affect the enzymatic hydrolysis result significantly. A model with $2^{3}$ factorial design in face centered central composite design with 6 star points $(\mathrm{a}=1)$ and 5 times center point replication $\left(\mathrm{n}_{0}=5\right)$ resulted 19 experimental variables that must be done to obtain optimum operational enzymatic hydrolysis value. This experiment was done in 2 time replication (duplo).

Table 2. Factors and code values of factorial design from Design Expert ${ }^{\circledR} 10$.

\begin{tabular}{|c|c|c|c|c|c|}
\hline \multirow{2}{*}{ Factor } & \multirow{2}{*}{ Variable } & \multirow{2}{*}{ Unit } & \multicolumn{3}{|c|}{ Coded Factor } \\
\cline { 4 - 6 } & & & $-\mathbf{1}$ & $\mathbf{0}$ & $+\mathbf{1}$ \\
\hline $\mathrm{A}$ & $\mathrm{pH}$ & - & 3 & 5 & 7 \\
\hline $\mathrm{B}$ & Temperature & ${ }^{\circ} \mathrm{C}$ & 30 & 40 & 50 \\
\hline $\mathrm{C}$ & $\begin{array}{c}\text { Hydrolysis } \\
\text { Time }\end{array}$ & Hours & 12 & 18 & 24 \\
\hline
\end{tabular}

The comparability between the model and experiments was done using Design Expert ${ }^{\circledR} 10$ by looking the R-square and adjusted R-square that gathered from the model and experiment. The validation was done by comparing the optimum value of reducing sugar yield from experiment to the predicted value of it.

\section{Result and Discussion}

\subsection{Coffee Pulp Pretreatment}

In this study, coffee pulp waste used for the main substrate was converted to reduce sugar. This waste was chosen due to the high content of cellulose and hemicellulose. Pretreatment process was done to break the solid structure lignin content inside coffee pulp waste, which could inhibit enzymatic hydrolysis process. Mechanical pretreatment was done to make the contact area of the coffee pulp waste wider and made it easier to be pretreated and hydrolyzed. The next step was chemical pretreatment process using organosolv method with citric acid and ethanol as a solvent. The coffee pulp and citric acid solution in a solid:liquid ratio was 1:16 w:w. The additions was obtained from previous studies (Pratiwi et al., 2010) using the best condition of cacao pulp. To improves the ethanol selectivity with respect to lignin and to improve the ability of ethanol delignifying, in this study, the addition of $\mathrm{NaOH} 4 \mathrm{~N}$ as catalyst agen during organosolv ethanol pretreatment (Mesa et al., 2011) was used. And then, 50\% ethanol was added to degrade lignin. The addition of citric acid aims to reduce the content of pectin in the coffee pulp. Based on previous study by (Mesa et al., 2011), sugarcane bagasse was conducted to a dilute-acid pretreatment $(0.2 \mathrm{M} \mathrm{H} 2 \mathrm{SO} 4$ solution in a solid:liquid ratio of $1: 5 \mathrm{w}: \mathrm{w}$, at $120^{\circ} \mathrm{C}$ for $\left.40 \mathrm{~min}\right)$. Then, it was followed by organosolv treatment, which was carried out in a $1000 \mathrm{ml}$ Parr reactor. Reactions were performed using the acid pretreated sugarcane bagasse and the ethanol and $\mathrm{NaOH}$ solution in a solid:liquid ratio of 1:7 w:w. In order to alleviate the corrosions caused by mineral acids in the acid-catalyzed ethanol pretreatment, in the previous study by (Zhao et al., 2009) was using acetic acid as catalyst instead of sulfuric acid.

Table 3. The Result of Pretreatment Process using 50\% Ethanol

\begin{tabular}{|c|c|c|c|}
\hline Substrate & $\begin{array}{c}\% \text { Cellulose } \\
(\mathrm{w} / \mathrm{w})\end{array}$ & $\begin{array}{c}\% \\
\text { Hemicellulose } \\
(\mathrm{w} / \mathrm{w})\end{array}$ & $\begin{array}{c}\% \text { Lignin } \\
(\mathrm{w} / \mathrm{w})\end{array}$ \\
\hline Untreated & 58.36 & 21,80 & 5,05 \\
\hline Pretreated & 66.82 & 25,08 & 0,12 \\
\hline
\end{tabular}

Table 3 shows that organosolv pretreatment method using $50 \%$ ethanol as the solvent able to degrade lignin content in coffee pulp waste significantly. It shows a 
significant effect, the lignin content degraded from 5.05\% to $0.12 \%$. Lignin was able to inhibit enzyme's activity during enzymatic hydrolysis. Based on previous study (Mesa et al., 2011), organosolv pretreatment process was able to degrade hemicellulose inside the substrate. However, the hemicellulose content was increasing, instead of degrading. Hemicellulose content in coffee pulp waste was not degraded due to the pretreatment temperature, which at $80^{\circ} \mathrm{C}$, therefore the hemicellulose content did not degrade (Widjaja et al., 2016).

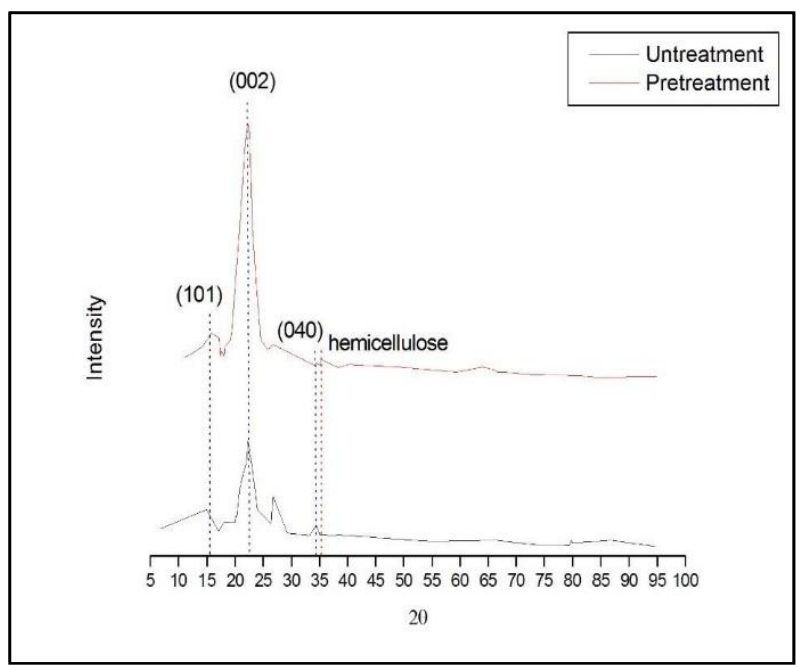

Fig. 1. XRD Analysis for Untreated and Pretreated Coffee Pulp Waste. Below the figure

In Figure 1, untreated coffee pulp waste shows diffraction peaks at $2 \theta=16^{\mathrm{O}} ; 22^{\mathrm{O}}$; and $34^{\mathrm{O}}$ which represent reflector plane (101); (002); and (040). The diffraction peaks shown in Figure 1 was similar to that from the former study done by Park et. al. in 2010, in which those peaks were common characteristic for original (untreated) cellulose crystalline (Park et al., 2010). After coffee pulp waste was treated using organosolv method with 50\% ethanol as the solvent, the reflector plane of (101) and (002) shows increasing in their intensity. The result of pretreated coffee pulp waste indicates the characteristics of cellulose II, that is commonly found in pretreated lignocellulosic biomass substrate using solvation and regeneration, in which the area of reflector plane (101) and (002) became wider (Xiao et al., 2012).

The increasing of cellulose crystalline after being pretreated using organosolv method made the reflector plane (101) and (002) areas became wider. The increasing of reflector areas implies that lignin content in coffee pulp waste was degraded (Sangian et al., 2015). $2 \theta=35^{\circ}$ reflector plane in untreated coffee pulp waste did not show any diffraction peak, however after the pretreatment process, it shows a little diffraction peak, which was hemicellulose reflector plane (Hamada et al., 2013). This means that after pretreatment process, hemicellulose content was increasing.

\subsection{Enzymatic Hydrolysis Optimization}

Optimization of enzymatic hydrolysis was done to get optimum operation condition in the enzymatic hydrolysis of pretreated coffee pulp waste. The aim of this optimization is to gather efficient operating condition in reducing sugar production process using enzymatic hydrolysis with pure cellulose enzyme nd pure xylanase enzyme combination. Enzymatic hydrolysis was the core process in bioethanol production process from lignocellulosic biomass. By optimizing hydrolysis process, the reducing sugar production yield would increase.

In this study, the optimization technique was carried out using response surface methodology (RSM). There were many kinds of variables that influence on the sugar production processes reduction, therefore central composite design (CCD) was used to determine the effect of each variable on the model of enzymatic hydrolysis process using coffee pulp waste as the substrate.

Based on ANOVA analysis in Table 4, the model used had significant effect of this experiment. This was shown by the value of F-value 78.81 and $p$-value (Prob $>F)$ which was less than 0.05 . The significance of each variable can be determined by the $\mathrm{p}$-value (Prob $>\mathrm{F}$ ). If this value was less than $0.05(<0.05)$, it means that the variable used in this process has significant effect in enzymatic hydrolysis result. In this experiment, $\mathrm{A}, \mathrm{B}, \mathrm{AB}, \mathrm{AC}, \mathrm{A}^{2}, \mathrm{ABC}, \mathrm{A}^{2} \mathrm{~B}$, and $A B^{2}$ were shown that those had significant effect to the model. The other variables did not show significant effect because $\mathrm{p}$-value (Prob $>$ F) bigger than $0.1(>0.1)$.

Table 4. ANOVA Result to the Response in Enzymatic Hydrolysis Process of Coffee Pulp Waste.

\begin{tabular}{|c|c|c|c|c|c|}
\hline Source & $\begin{array}{l}\text { Sum of } \\
\text { Squares }\end{array}$ & $\begin{array}{c}\text { Degree } \\
\text { of } \\
\text { Freedo }\end{array}$ & $\begin{array}{c}\text { Mean } \\
\text { Square }\end{array}$ & F Value & $\begin{array}{c}\text { p-Value } \\
(\text { Prob }>\text { F })\end{array}$ \\
\hline Model & 0.055 & 13 & $\begin{array}{c}4.224 \mathrm{x} \\
10^{-3}\end{array}$ & 78.81 & $<0.0001$ \\
\hline $\mathrm{A}: \mathrm{pH}$ & $\mid \begin{array}{c}4.410 \mathrm{x} \\
10^{-4}\end{array}$ & 1 & $\begin{array}{c}4.410 \mathrm{x} \\
10^{-4}\end{array}$ & 8.23 & 0.0085 \\
\hline $\begin{array}{c}\text { B: } \\
\text { Temperature }\end{array}$ & $\begin{array}{c}8.07 \mathrm{x} \\
10^{-4}\end{array}$ & 1 & $\begin{array}{c}8.074 \mathrm{x} \\
10^{-4}\end{array}$ & 15.06 & 0.0007 \\
\hline \begin{tabular}{|c|}
$\mathrm{C}:$ \\
Hydrolysis \\
Time
\end{tabular} & $\begin{array}{c}4.134 \mathrm{x} \\
10^{-5}\end{array}$ & 1 & $\begin{array}{c}4.134 \mathrm{x} \\
10^{-5}\end{array}$ & 0.77 & 0.3885 \\
\hline $\mathrm{AB}$ & 0.017 & 1 & 0.017 & 309.28 & $<0.0001$ \\
\hline $\mathrm{AC}$ & $\begin{array}{c}5.531 \mathrm{x} \\
10^{-4}\end{array}$ & 1 & $\begin{array}{c}5.531 \mathrm{x} \\
10^{-4}\end{array}$ & 10.32 & 0.0037 \\
\hline $\mathrm{BC}$ & $\mid \begin{array}{c}3.525 \mathrm{x} \\
10^{-5}\end{array}$ & 1 & $\begin{array}{c}3.525 \mathrm{x} \\
10^{-5}\end{array}$ & 0.66 & 0.4253 \\
\hline$A^{2}$ & $\begin{array}{c}2.758 \mathrm{x} \\
10^{-3}\end{array}$ & 1 & $\begin{array}{c}2.758 x \\
10^{-3}\end{array}$ & 51.45 & $<0.0001$ \\
\hline $\mathrm{B}^{2}$ & $\begin{array}{c}7.875 \mathrm{x} \\
10^{-5}\end{array} \mid$ & 1 & $\begin{array}{c}7.875 \mathrm{x} \\
10^{-5}\end{array}$ & 1.47 & 0.2373 \\
\hline
\end{tabular}




\begin{tabular}{|c|c|c|c|c|c|}
\hline Source & $\begin{array}{l}\text { Sum of } \\
\text { Squares }\end{array}$ & $\begin{array}{c}\text { Degree } \\
\text { of } \\
\text { Freedo }\end{array}$ & $\begin{array}{l}\text { Mean } \\
\text { Square }\end{array}$ & F Value & $\begin{array}{c}\text { p-Value } \\
\text { (Prob }>\text { F) }\end{array}$ \\
\hline$C^{2}$ & $\begin{array}{c}1.456 \mathrm{x} \\
10^{-4}\end{array}$ & 1 & $\begin{array}{c}1.456 \mathrm{x} \\
10^{-4}\end{array}$ & 2.72 & 0.1124 \\
\hline $\mathrm{ABC}$ & $\begin{array}{c}1.329 \mathrm{x} \\
10^{-3}\end{array}$ & 1 & $\begin{array}{c}1.329 \mathrm{x} \\
10^{-3}\end{array}$ & 24.80 & $<0.0001$ \\
\hline $\mathrm{A}^{2} \mathrm{~B}$ & $\begin{array}{c}1.338 \mathrm{x} \\
10^{-3}\end{array}$ & 1 & $\begin{array}{c}1.338 \mathrm{x} \\
10^{-3}\end{array}$ & 24.95 & $<0.0001$ \\
\hline $\mathrm{A}^{2} \mathrm{C}$ & $\begin{array}{c}2.102 \mathrm{x} \\
10^{-4}\end{array}$ & 1 & $\begin{array}{c}2.102 \mathrm{x} \\
10^{-4}\end{array}$ & 3.92 & 0.0593 \\
\hline $\mathrm{AB}^{2}$ & $\begin{array}{c}3.369 \mathrm{x} \\
10^{-3}\end{array}$ & 1 & $\begin{array}{c}3.369 \mathrm{x} \\
10^{-3}\end{array}$ & 62.85 & $<0.0001$ \\
\hline $\mathrm{AC}^{2}$ & 0 & 0 & & & \\
\hline $\mathrm{B}^{2} \mathrm{C}$ & 0 & 0 & & & \\
\hline $\mathrm{BC}^{2}$ & 0 & 0 & & & \\
\hline$A^{3}$ & 0 & 0 & & & \\
\hline $\mathrm{B}^{3}$ & 0 & 0 & & & \\
\hline$C^{3}$ & 0 & 0 & & & \\
\hline Residual & $\begin{array}{c}1.286 \mathrm{x} \\
10^{-3}\end{array}$ & 24 & & & \\
\hline Lack of Fit & \begin{tabular}{|c|}
$5.708 x$ \\
$10^{-5}$ \\
\end{tabular} & 1 & & 1.07 & 0.3122 \\
\hline Pure Error & $\begin{array}{c}1.229 \mathrm{x} \\
10^{-3}\end{array}$ & 23 & & & \\
\hline Total & 0.056 & 37 & & & \\
\hline
\end{tabular}

$\mathrm{R}^{2}=0.9771 ;$ adjusted $\mathrm{R}^{2}=0.9647$

Lack of fit value of 1.07 indicates that the lack of fit in this model did not have significant effect on the pure error. This means that the model can be used for the experiment. Besides the determination coefficient, $\mathrm{R}^{2}$ value of 0.9771 reveals that the model was significant and was able to be used in this experiment. $\mathrm{R}^{2}$ value which was bigger than 0.75 (>0.75) implies that the model can be used properly.

In this experiment, the variables that have significant effect on enzymatic hydrolysis process of coffee pulp waste were $\mathrm{pH}$ and hydrolysis temperature based on the $\mathrm{p}$ value (Prob $>$ F) of 0.0085 and 0.0007 respectively. This result was in a good agreement with the previous study that shows that $\mathrm{pH}$ and hydrolysis temperature had significant effect on enzymatic hydrolysis process of lignocellulosic biomass (Ferreira et al., 2009). It was due to substrate and enzyme bonding role during hydrolysis process and the movement of substrate to active side of the enzyme which was affected by buffer type. In this process, citric acid buffer had better effect than acetate buffer for enzymatic hydrolysis process (Peña-Farfal et al., 2004). Temperature had significant effect on enzymatic hydrolysis process, in which enzymatic hydrolysis process in mild temperature $\left(45-50^{\circ} \mathrm{C}\right)$ would obtain the best result of reducing sugar (Duff and Murray, 1996).

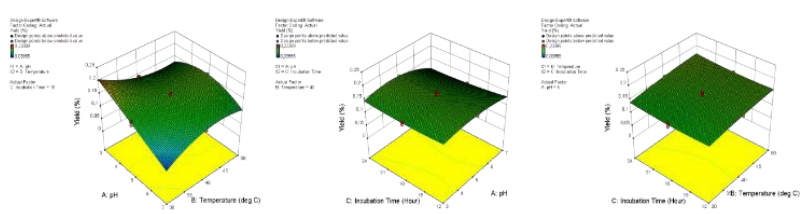

Fig. 2. Depicts Response Surface with Central Composite Design Plot in the Optimization of Enzymatic Hydrolysis to the Yield of produced Reducing Sugar which shows: (a) pH against Temperature, (b) Hydrolysis Time against $\mathrm{pH}$, dan (c) Hydrolysis Time against Temperature. Below the figure

The equation gathered from response surface methodologywas the connection among the manipulated variables that was used during enzymatic hydrolysis process, which was the response yield of produced reducing sugar. The equation was:

$$
\begin{gathered}
\text { Yield }=1.912+7.595 \times 10^{-5} a b c-5 \times 10^{-4} a^{2} b-3.377 \times 10^{-4} a^{2} c-1.6 \times 10^{-4} a b^{2} \\
+0.021 a^{2}+7.620 \times 10^{-4} b^{2}+1.434 \times 10^{-4} c^{2}+0.018 a b-1.513 \times \\
10^{-4} a c-3.550 \times 10^{-4} b c-0.468 a-0.074 b+3.583 \times 10^{-3} c
\end{gathered}
$$

(1)

$\mathrm{a}, \mathrm{b}$, and $\mathrm{c}$ values were actual value in various $\mathrm{pH}$, temperature, and hydrolysis time condition. The equation was then solved to get optimal value of each variable to the response. The optimization process was using Design Expert ${ }^{\circledR} 10$ and this is shown in Table 5.

Based on Table 5, optimum reducing sugar yield from experiments was 0.137 gram of reducing sugar / gram (cellulose + hemicellulose) with error value of 0.065 . The experiment value was in a good agreement compared to predicted yield value of 0.147 gram of reducing sugar / gram (cellulose + hemicellulose) with reducing sugar yield range of $0.03955-0.23389$ gram of reducing sugar / gram (cellulose + hemicellulose). From the experimental result, it can be concluded that the model was in a good agreement to the experiment.

Table 5. Predicted and Actual Yield with Optimum Value of Each Variable.

\begin{tabular}{|l|l|l|l|l|}
\hline \multicolumn{2}{|c|}{ Variables } & \multirow{2}{*}{$\begin{array}{c}\text { Predicted } \\
\text { Yield }\end{array}$} & $\begin{array}{c}\text { Actual } \\
\text { Yield }\end{array}$ & Error \\
\hline $\mathrm{pH}$ & 4.63 & & & \\
\cline { 1 - 2 } Temperature & $34^{\mathrm{O}} \mathrm{C}$ & \multirow{2}{*}{0.147} & 0.137 & 0.065 \\
\cline { 1 - 2 } $\begin{array}{l}\text { Hydrolysis } \\
\text { Time }\end{array}$ & $\begin{array}{l}16.29 \\
\text { hours }\end{array}$ & & & \\
\hline
\end{tabular}

From the previous study, the optimum condition of enzymatic hydrolysis was at $\mathrm{pH}$ 4.5-5.0 with hydrolysis temperature at $40-50^{\circ} \mathrm{C}$. Enzymatic hydrolysis had several benefits compared to other hydrolysis methods which had mild condition of hydrolysis, did not have corrosiveness and less utility needs. In addition, the hydrolysate that was produced contained less toxic agents or components that were able to inhibit fermentation process. For those reasons, enzymatic hydrolysis was widely used compared to other hydrolysis method. Meanwhile, the $\mathrm{pH}$ value of 4.63 in this study was in a good agreement compared to that in the previous 
study. However, the optimized value of hydrolysis temperature $\left(34^{\circ} \mathrm{C}\right)$ was a little bit lower compared to that in the previous study $\left(40-50^{\circ} \mathrm{C}\right)$. The difference happened due to the different substrate that was used in enzymatic hydrolysis process and the combination of enzyme type used. Optimum temperature was affected by hydrolyzed substrate, enzyme type as the hydrolysis agent, and hydrolysis time (Palmqvist and HahnHägerdal, 2000). Optimum hydrolysis time in enzymatic hydrolysis for coffee pulp waste was 16.29 hours. From previous experiments, the substrate was still able to be hydrolyzed after 16.29 hours of hydrolysis time, but this result would be another problem for further process because the reducing sugars can be inhibitor for enzymatic hydrolysis process (Linde et al., 2007). In short, it can be concluded that optimum value of hydrolysis time in enzymatic hydrolysis was 16.29 hours.

\section{Conclusion}

From the experiments and analysis, it can be concluded that organosolv method pretreatment using $50 \%$ ethanol as the solvent was able to increase both cellulose and hemicellulose content to $66.82 \%(\mathrm{w} / \mathrm{w})$ and $25.05 \%$ $(\mathrm{w} / \mathrm{w})$, respectively. This process has significant effect in lignin degradation in coffee pulp waste that was shown by the decreasing of lignin content from $5.05 \%$ $(\mathrm{w} / \mathrm{w})$ to $0.12 \%(\mathrm{w} / \mathrm{w})$.

The optimization of enzymatic hydrolysis process using combination of pure cellulose and xylanase enzyme using response surface methodology producing $\mathrm{pH}$ value of 4.63 , hydrolysis temperature of $34^{\circ} \mathrm{C}$, and hydrolysis time for 16.29 hours with predicted reducing sugar yield of 0.147 gram reducing sugar / gram (cellulose + hemicellulose). From ANOVA analysis, it shows that $\mathrm{pH}$ and hydrolysis temperature had significant effect on enzymatic hydrolysis process of coffee pulp waste.

The authors would like to express their deepest gratitude to Ministry of Research, Technology and Higher Education of the Republic of Indonesia for providing financial support for carrying out this research with research's contract number: 179/SP2H/LT/DRPM/III/2016.

\section{References}

1. Cardona, C.A., Sánchez, Ó.J., 2007. Fuel ethanol production: Process design trends and integration opportunities. Bioresour. Technol. 98, 2415-2457.

2. Chandra, R., Takeuchi, H., Hasegawa, T., 2012. Hydrothermal pretreatment of rice straw biomass : A potential and promising method for enhanced methane production. Appl. Energy 94, 129-140.

3. Domanski, J., Borowski, S., Marchut-Mikolajczyk, O., Kubacki, P., 2016. Pretreatment of rye straw with aqueous ammonia for conversion to fermentable sugars as a potential substrates in biotechnological processes. Biomass and Bioenergy 91, 91-97.
4. Duff, S.J.B., Murray, W.D., 1996. Bioconversion of forest products industry waste cellulosics to fuel ethanol: A review. Bioresour. Technol. 55, 1-33.

5. Ferreira, S., Duarte, A.P., Ribeiro, M.H.L., Queiroz, J.A., Domingues, F.C., 2009. Response surface optimization of enzymatic hydrolysis of Cistus ladanifer and Cytisus striatus for bioethanol production. Biochem. Eng. J. 45, 192-200.

6. Geng, A., Xin, F., Ip, J. yu, 2012. Ethanol production from horticultural waste treated by a modified organosolv method. Bioresour. Technol. 104, 715721.

7. Hahn-Hägerdal, B., Galbe, M., Gorwa-Grauslund, M.F., Lidén, G., Zacchi, G., 2006. Bio- ethanol - the fuel of tomorrow from the residues of today. Trends Biotechnol. 24, 549- 556.

8. Hamada, Y., Yoshida, K., Asai, R., Hayase, S., Nokami, T., Izumi, S., Itoh, T., 2013. A possible means of realizing a sacrifice-free three component separation of lignocellulose from wood biomass using an amino acid ionic liquid. Green Chem. 15, 1863.

9. Linde, M., Galbe, M., Zacchi, G., 2007. Simultaneous saccharification and fermentation of steam-pretreated barley straw at low enzyme loadings and low yeast concentration.

10. Enzyme Microb. Technol. 40, 1100-1107.

11. Mesa, L., González, E., Cara, C., González, M., Castro, E., Mussatto, S.I., 2011. The effect of organosolv pretreatment variables on enzymatic hydrolysis of sugarcane bagasse. Chem. Eng. J. 168, 1157-1162.

12. Palmqvist, E., Hahn-Hägerdal, B., 2000. Fermentation of lignocellulosic hydrolysates. I: Inhibition and detoxification. Bioresour. Technol. 74, 17-24.

13. Park, S., Baker, J.O., Himmel, M.E., Parilla, P. a, Johnson, D.K., 2010. Cellulose crystallinity index: measurement techniques and their impact on interpreting cellulase performance. Biotechnol. Biofuels 3, 10.

14. Peña-Farfal, C., Moreda-Piñeiro, A., BermejoBarrera, A., Bermejo-Barrera, P., Pinochet- Cancino, H., De Gregori-Henríquez, I., 2004. Use of enzymatic hydrolysis for the multi- element determination in mussel soft tissue by inductively coupled plasmaatomic emission spectrometry. Talanta 64, 671-681.

15. Pratiwi, Eka, Yatim, Endahwati, L., 2010. Pemanfaatan limbah kulit buah cokelat sebagai bioetanol. Makal. Semin. Nas. Tek. Kim. Soebardjo Brotohardjono "Ketahanan Pangan dan Energi" 110.

16. Sangian, H.F., Kristian, J., Rahma, S., Agnesty, S.Y., Gunawan, S., Widjaja, A., 2015.

17. Comparative Study of the Preparation of Reducing Sugars Hydrolyzed from High-Lignin Lignocellulose Pretreated with Ionic Liquid, Alkaline Solution and 
Their Combination. J. Eng. Technol. Sci. 47, 137148.

18. Sun, Y., Cheng, J., 2002. Hydrolysis of lignocellulosic materials for ethanol production: a review q. Bioresour. Technol. 83, 1-11.

19. Widjaja, T., Altway, A., Ni'Mah, H., Tedji, N., Rofiqah, U., 2015. Technique of ethanol food grade production with batch distillation and dehydration using starch-based adsorbent. AIP Conf. Proc. 1699.

20. Widjaja, T., Altway, A., Nurkhamidah, S., Edahwati, L., Lini, F.Z., Oktafia, F., 2016. The Effect of Pretreatment and Variety of Microorganisms to The Production of Ethanol from Coffee Pulp 11, 10561060.

21. Widjaja, T., Altway, A., Permanasari, A.R., Gunawan, S., 2014. Production of Ethanol As A Renewable Energy by Extractive Fermentation. Appl. Mech. Mater. 493, 300-305.

22. Widjaja, T., Iswanto, T., Altway, A., Shovitri, M., Rachmania Sri, J., 2017. Methane Production from Coffee Pulp by Microorganism of Rumen Fluid and Cow Dung in Co- digestion. Chem. Eng. Trans. 56, 1465-1470.

23. Xiao, W., Yin, W., Xia, S., Ma, P., 2012. The study of factors affecting the enzymatic hydrolysis of cellulose after ionic liquid pretreatment. Carbohydr. Polym. 87, 2019- 2023.

24. Zaldivar, J., Nielsen, J., Olsson, L., 2001. Fuel ethanol production from lignocellulose: A challenge for metabolic engineering and process integration. Appl. Microbiol.

25. Biotechnol. 56, 17-34.

26. Zhao, X., Cheng, K., Liu, D., 2009. Organosolv pretreatment of lignocellulosic biomass for enzymatic hydrolysis. Appl. Microbiol. Biotechnol. $82,815-827$ 